\author{
Justyna Mokras-Grabowska \\ University of Łódź \\ Institute of Urban Geography and Tourism Studies \\ Department of Leisure and Qualified Tourism \\ justyna.mokras_grabowska@op.pl
}

\title{
ART-TOURISM SPACE IN ŁÓDŹ: THE EXAMPLE OF THE URBAN FORMS GALLERY
}

\begin{abstract}
Polish tourism destination whose urban fabric constitutes a perfect background for street art. Examples are the murals of the Urban Forms Gallery (large format artworks) which contribute to revitalisation as well as the creation of new tourism assets to form a new tourism space: art-tourism space. The paper describes both the process of creating this space as well as its distinctive features.
\end{abstract}

Key words: tourism space, art-tourism space, street art, murals of the Urban Forms Gallery in Łódź.

\section{INTRODUCTION}

In contemporary tourism, one remarkable phenomenon is the continuously expanding spectrum of new assets functioning as objects of tourism interest. This includes city offers, particularly those seeking new ways of economically activating a city after the collapse of industry. After their urban status has been reduced and degradation has progressed they are perceived as unattractive, neglected and face a number of social and economic problems. They are often regarded as places not worth any tourism interest and often require the creation of new tourism attractions (KACZMAREK 2001, p. 32).

It may be concluded that until the 1990s, concerning tourism, cities in Poland were mainly perceived in recreation, cognitive and pilgrimage terms (LISZEWSKI 2008 , p. 29). Along with the growth of a market economy, new ways of economically activating cities have occurred. A new tourism landscape is being created and new geographical spaces are incorporated for tourism purposes, connected with a new tourism trend: the search for new experiences (STASIAK 2013, p. 66).

Łódź is such a city - a place with a specific tourism potential associated with its post-industrial character. $19^{\text {th }} \mathrm{c}$. textile industrial development has left its mark on the cultural landscape of the city and has become its symbol. Industrial complexes with their redbrick factories are a dominant feature and constitute a significant tourism asset both before and after revi- talisation (e.g. 'Manufaktura' shopping mall) distinguishing it from other Polish cities.

Activities connected with street art, contemporary art, creative industries ${ }^{1}$ and so-called 'off-culture' perfectly fit into its post-industrial sphere and constitute an alternative to mainstream culture.

Łódź is in fact a city of modern art - the Łódź avant-garde flourished here in interwar period, mainly due to such great revolutionary artists as Władysław Strzemiński and Katarzyna Kobro who created an avant-garde image of the city (Strategia zarzadzania marką...).

Łódź is a city looking for new trends - the first neoavant-garde exhibition 'Construction under process' took place in 1980 in Łódź and it continues as the interdisciplinary, contemporary art exhibition 'Łódź Biennale'.

Łódź is finally a city of murals (large format artworks). Urban Forms Foundation (set up in 2009) promotes independent artistic initiatives, of which the most important and remarkable is the Urban Forms Gallery, an exhibition of street art set in an urban space.

All these activities, in association with the postindustrial, urban fabric of the city, mean that Łódź is a place of creative exploration, a distinctive Polish tourism destination, in which the creation of a new urban space is currently being experienced. Art- 
tourism space being understood here as both a contemporary and modern art space.

This article refers only to a selected area of modern art; to the street art activities of the Urban Forms Foundation known as the Urban Forms Gallery (a gallery of large format artworks, murals).

\section{STREET ART - SOME BASIC TERMS}

Reflections on the development of a new urban space (art-tourism space) should begin with the presentation of some important definitions. It should be emphasised too that street art does not appear in the geography of tourism studies, including that connected with tourism space. Street art is usually recognized as an art, in terms of new aesthetics and dialogue in an urban space (NIŻYŃSKA 2011, STĘPIEŃ 2010).

Street art has its roots in graffiti. In former times a graffito meant a pattern scratched onto a surface (NIŻYŃSKA 2011, p. 67). The history of graffiti in Poland includes anti-Russian inscriptions which appeared in Warsaw in the 19th c. During World War II graffiti meant descriptions on walls ridiculing the occupant. Anti-communist opposition activities in Poland had a similar context (especially in the 80s). One early major initiative in the field of street art was the so-called 'Orange Alternative' in Wroclaw, during which a figure of a dwarf was added to anticommunist slogans on the sides of buildings. The 'Orange Alternative' consisted of a series of street art activities such as happenings and performances in which the most important element was a surrealism breaking the rules of the communist system.

While graffiti is the marking of the presence of its producer in a public space, not communicating an idea and not having high artistic value or aesthetic, street art is much more advanced and operates within a number of forms and ideas (NIŻYŃSKA 2011, p. 74). There is no single definition of street art - it is open to new projects and ideas. Visual and performance street art can be singled out.

Visual street art operates with such techniques as templates ${ }^{3}$, stickers ${ }^{4}$, cut-outs ${ }^{5}$ and murals ${ }^{6}$.

Mural is a word of Spanish origin meaning decorative wall painting (STĘPIEŃ 2010, p. 5) and its origins date back to the 1920s and 30s when it gained particular fame in Latin America. The first mural artists included David Alfaro Siqueiros, Jose Clemente Orozco and Diego Riviera.

Performance street art, in turn, means activities in a public sphere. An example are flash mobs aiming at involving as many random people as possible to do the same, absurd, surprising activity in an urban space.
The essence of street art is a public space in which the ideas and opinions of artists are being expressed. Moreover, the creation of the space takes place, including its ability to renew and transform unattractive, degraded landscapes. It is because of these, in old, mature, and new tourism spaces, as well in nontourism space, that restructuring processes take place which lead to change in the public sphere (WŁODARCZYK 2011, p. 62).

In a review of concepts associated with the creation of large format artworks in Łódź, the term 'revitalization' is crucial. In analysing its etymology ('re' - again, 'vitalis' - giving life) it can be seen that creating murals is a kind of revitalization.

As DOMAŃSKI claims (2010, p.23) revitalization is a process of creation in the public sphere. It is also a kind of reaction to degradation (technical, social and economic).

Although the most important role of revitalization is to equip an area with new functions it also means its revival (after collapse, crisis, degradation) and adding new value (KACZMAREK 2001, p. 17). These qualitative changes lead to a rise in the status and prestige of urban space - a new image of the city is created.

For such activities, however, it seems appropriate to use other terms: regeneration, revival, renewal; which are often used interchangeably in the English literature. These terms better reflect the process of restoring the former splendour of neglected sites and give them a new quality (but not function). According to S. KACZMAREK (2001, p. 32) the revitalization process includes that of its image.

Areas formerly perceived as unattractive and dangerous, after renewal start to be distinguished as a positive element in the city and thus become a symbol of modernity, creativity and development, enriching the city with a new aesthetic (KACZMAREK 2001, p. 36). The quality and meaning of its space changes; it becomes perceived differently by both locals and tourists.

\section{MURALS IN ŁÓDŹ: A NEW ELEMENT IN AN URBAN SPACE}

The first murals in Łódź were created in communist times and were a kind of huge advertisement confirming the presence of an enterprise. They were also a kind of symbol for artists. In the production of large format artworks in Łódź, an important part of their meaning was to cover the demolition of the entire frontage of streets in particular areas in the very centre of the city - Zachodnia-Kościuszki and PiłsudskiegoMickiewicza. Elevations of buildings were revealed and enterprises could present their advertisements (in 
the form of large became a way of disguising the neglected walls of downtown tenement houses). The most famous artist in this field in Łódź was Andrzej Feliks Szumigaj who created murals inspired by opart in compositions using multiple, multi-coloured squares (Photos 1 \& 2). The group Arabski-JaeschkeTranda, in turn, elaborated a style based on a form of lozenge. Other famous artists connected with murals were Zdzisław Fryczka, Zbigniew Łopata, Bogumił Łukaszewski and Roman Szybilski (STĘPIEŃ 2010, pp. 17-19).
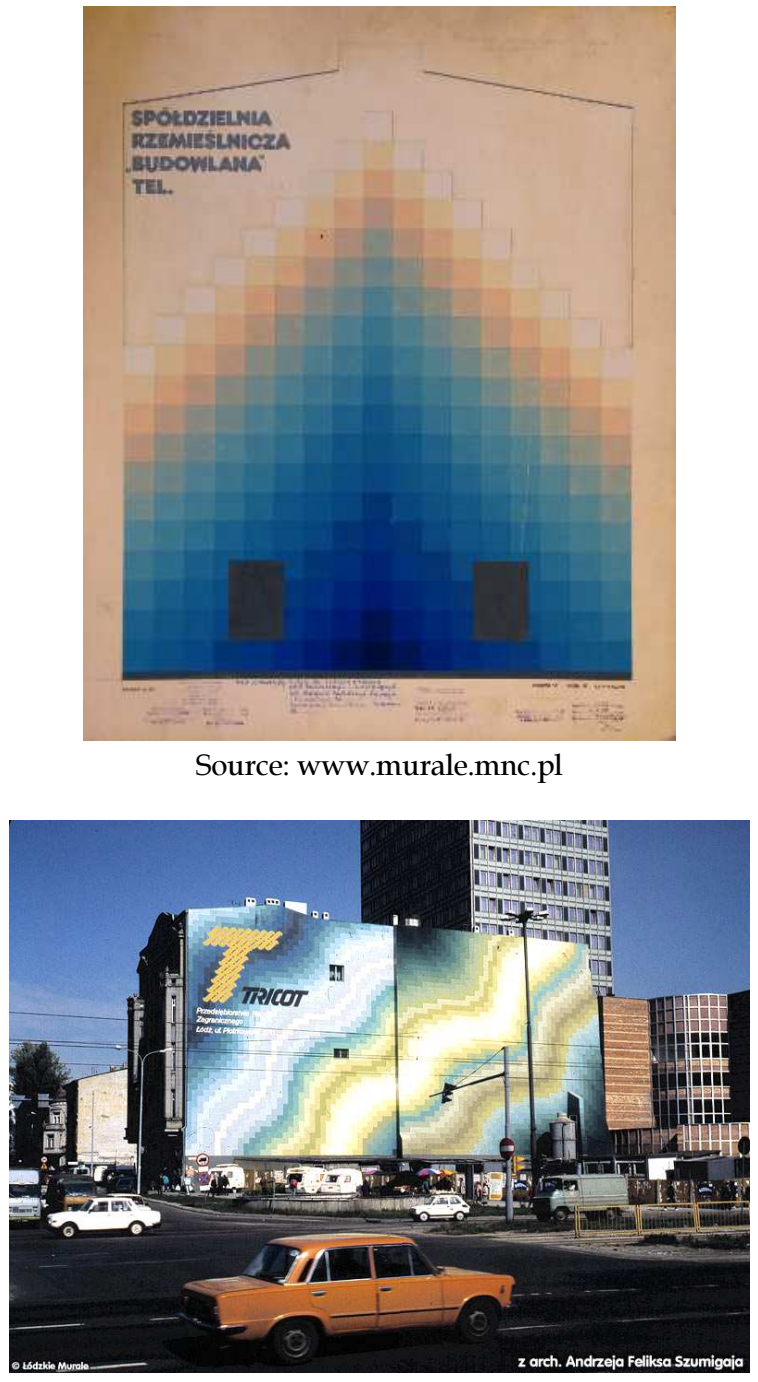

Source: www.lodzdesign.com

Photos 1 \& 2 . Murals by Andrzej Feliks Szumigaj in Łódź

After the collapse of communism in 1989, art projects became more commercial. Most of the original murals were painted over but after a few years were revealed once more as a result of the new paint flaking away. Murals created in those times had a very simplified, computer-designed form (logo and inscription).
The opening of the Museum of Art in the 'Manufaktura' shopping mall in 2008 marked a new beginning for murals in Łódź and the first city tour of the murals in Łódź was organized. Interest in street art was gradually increasing. Amateur artists began to be recognized and gained an increasing audience. The allegory of the city on 152 Piotrkowska St created by Design Futura Group in 2001 was the first large scale street art project in Łódź although significantly differing from the other murals created at that time (Photo 3).

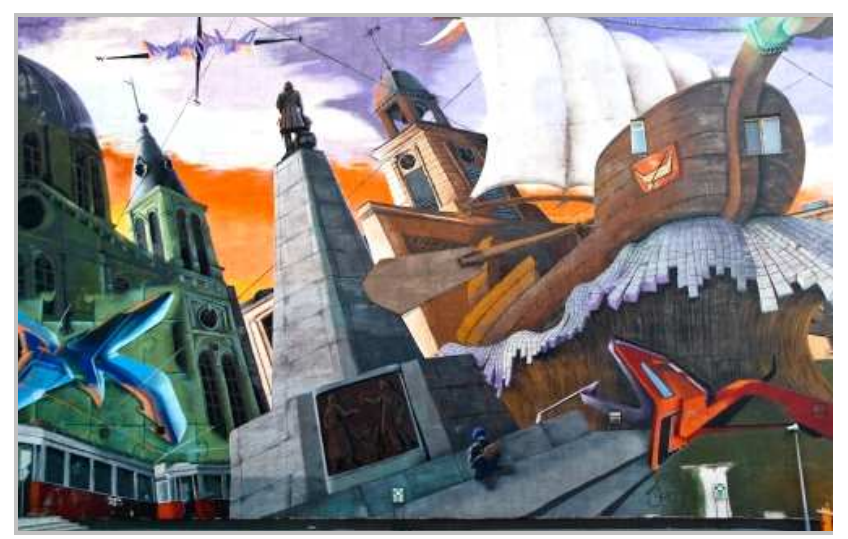

Photo 3. Mural at 152 Piotrkowskia St, Łódź Source: www.panoramio.com

Currently the post-industrial urban space in Łódź constitutes a perfect background for street art activities. The major achievements in this area have been through the Urban Forms Foundation which promotes unique cultural activities devoted to the community in Łódź (social revitalization). The main mission of the Foundation is to saturate the urban fabric with creative modern art to improve the city's image by giving it a new and original character. The aim is therefore to create an artistic urban asset.

The tool used in its mission is the large scale artwork created on the walls of downtown tenement houses and on the elevations of apartment blocks on housing estates. As a result of this Urban Forms Gallery is being created with the project promoting 'living' culture and art. The Gallery is a permanent exhibition of street art created in the urban sphere of Łódź which currently consists of over 30 large format artworks which make up a public art trail.

The project is co-financed by the Town Hall of Łódź under the patronage of the mayor. Over the next few years the project will be extended by further urban artworks (sculpture, installations etc).

An important issue for the project is the high artistic value of the murals created. Their artists are outstanding representatives of large format artworks from around the world presenting a diverse range of 
artistic concepts. The most important include GEMEOS (Brazil), ARYZ (Spain), REMED (France), INTI (Chile), SAT ONE (Germany), SHIDA (Australia) and Polish artists: ETAM CREW, M-CITY, LUMP.

The Urban Forms Foundation aims at a long lasting change to the aesthetic of the city of Łódź and associating it with innovative art placed in public space. This 'live gallery' of modern art constitutes a symbol for the city - the activities are not only conceptual, but also clear and understandable for its audience. The present research carried out in 2014 evaluated opinions about the creation of murals in the public sphere and produced interesting results (Dialogi wokót murali... 2014). There is a widespread belief that 'murals are beautifying and brightening the streets and reviving neglected areas'. Vivid colour is seen as dominant, therefore, not artistic content and message - many respondents could not describe the theme of a mural. The need for realistic depictions, comprehensible to their audience, was pointed out ('positive content and emotions').

\section{ART-TOURISM SPACE IN ŁÓDŹ: THE EXAMPLE OF THE URBAN FORMS GALLERY}

As emphasised above, a characteristic feature of modern tourism is the constantly growing spectrum of new assets becoming tourism attractions (LISZEWSKI 1999) contributing to the creation of a new landscape for the city. Such a creative tourism destination gives tourists an opportunity to interact in an urban space. It allows new products to be introduced in a relatively short period of time, to give a place a competitive advantage (NOWACKI 2011, p. 20).

Bearing in mind that tourism is based on a continuous process of creation its potential is constantly evolving (NOWACKI 2011, p. 21). Such activities may therefore complement tourism products, especially in places poor in tourism resources. The essence here is to allow visitors to create their own narrative based on imagination. The formation of large format artworks gives such opportunities. In urban areas a new tourism space has appeared; a symbol of modernity, fashion, enriching the city materially and raising its status. It covers over the negative, post-industrial landscape of the city, its poverty, negligence and unattractiveness (KRONENBERG 2012, p. 24).

It is worth mentioning that with the passage of time and increased community awareness, the artistic value of post-industrial urban space develops alongside various creative activities (including street art).

The formation of a new tourism space fits into the concept of the experience economy of Pine \& Gilmore who discuss selling emotions and experiences (STASIAK 2013, p. 65). This phenomenon is associated with the exploration of new places and opportunities for recreation to provide the participants with new experience. Thus, areas that until recently did not arouse much tourism interest, have become a tourism destination. Travelling beyond the exploration of 'traditional attractions', is defined as 'tourism-off-thebeaten-track'. For art-tourism space, the scenery of destroyed buildings and the atmosphere of time passing have crucial meanings (STASIAK 2013, p. 69), especially connected with a post-industrial landscape, giving an excellent opportunity to explore unsightly districts of the city.

A new urban aesthetic is being created. In postindustrial cities, in terms of industrial heritage, a kind of 'techno-aesthetic' appears (KRONENBERG 2012). It should be emphasised, however, that it requires a mature audience bringing with it a fresh perspective and also the desire to build something new - something non-sterile, of a new quality often avant-garde and even abstract in message.

The audience has its own sensitivity, aesthetic, set of impressions and experience, subjective identity, self-awareness and knowledge. Important background conditions are lighting, sound, smell and even who you are with (AFFELT 2009, p. 36).

Art-tourism space is a part of an urban tourism space which is distinguished from general urban space. This, in turn, is a distinctive type of geographical space characterized by a specific organization, function, physiognomy and legal status (LISZEWSKI 1999, p. 51-52).

Under certain conditions of city development, urban space is considered interesting in terms of cognitive tourism and recreation. This leads to the formation of an urban tourism space (LISZEWSKI 1999, p. 54) whose basic criterion is the presence of tourism.

In this paper it is important to distinguish, within the limits of tourism space, two types of previously non-tourism space: unknown space (lack of information limits the tourists) and unwanted space (rejected as it is not recognized as touristically valuable) (WŁODARCZYK 2009, p. 93-94).

Considering the mural trail, the artworks are created on the walls of neglected downtown tenement houses or on the elevations of apartment blocks, and before these sites had not constituted a tourism asset. The appearance of large format artwork resulted in an influx of tourists, both individual and in groups (organized by the Urban Forms Foundation). Therefore the former non-tourism urban space has been transformed into a tourism space.

According to the location of murals within the urban fabric, the art-tourism space of the Urban Forms Gallery in Łódź can be divided into four types (Fig. 1): 


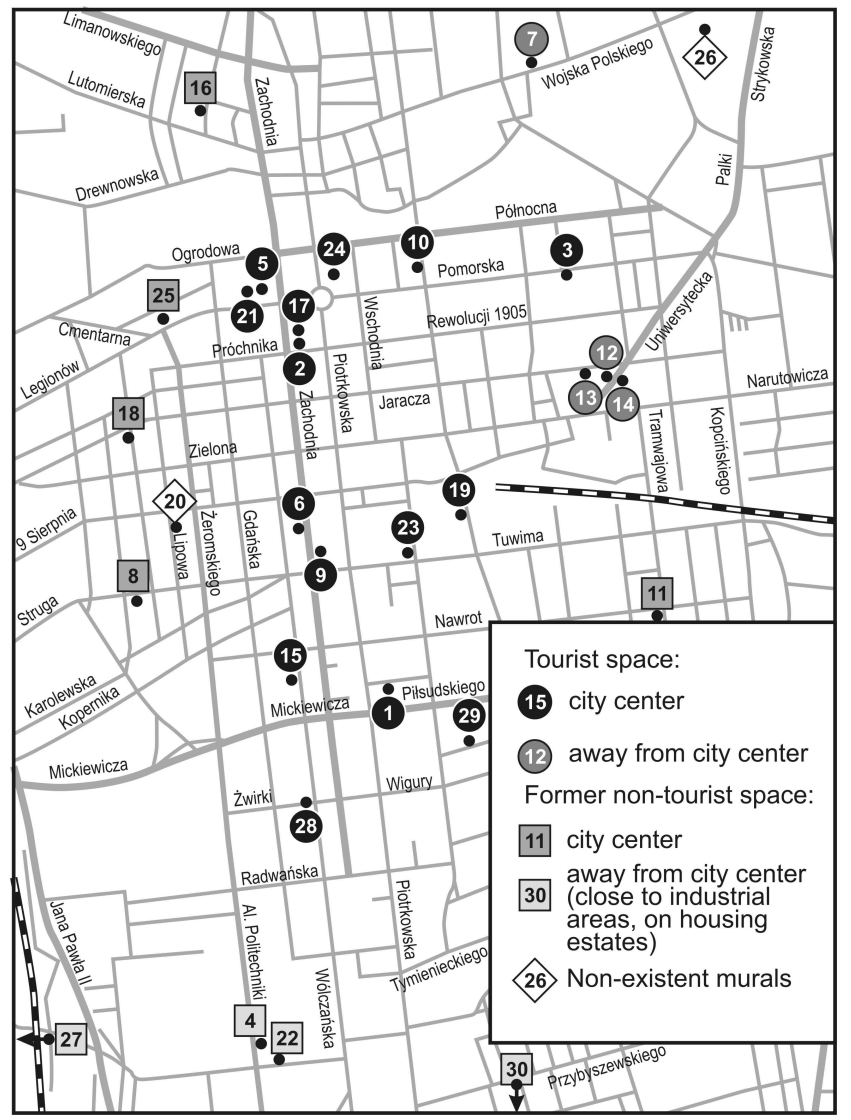

Key: 1 - 5 Roosevelta St (OS GEMEOS/ARYZ), 2 - 11 Próchnika St (REMED), 3-67 Pomorska St (ARYZ), 4-16 Politechniki St (ARYZ), 5 - 19 Legionów St (M-CITY), 6 - 27 Kościuszki St (SAT ONE/ETAM CREW), 7 - 82 Wojska Polskiego St (SHIDA), 8 - 48 Pułku Strzelców Kaniowskich St (INTI), 9 - 32 Kościuszki St (KENOR), 10 - 28 Pomorska St (KENOR), 11 - 81 Nawrot St (ETAM CREW), 12 - 12 Uniwersytecka St (SAINER), 13 - 59 Jaracza St (GREGOR), 14 - 3 Uniwersytecka St (ETAM CREW), 15 - 109 Wólczańska St (LUMP), 16 - 2/4 Rybna St (OTECKI), 17 - 9 Próchnika St (SEPE), 18 - 25 Pogonowskiego St (MASSMIX), 19 - 73 Kilińskiego St (KRIK), 20 - 44 Lipowa St (no longer existing) (GREGOR/CIACH CIACH), 21 - 27 Legionów St (PENER), 22 - 16 Politechniki St (ETAM CREW), 23 - 5 Nowomiejska St (ROA), 24 - 16 Tuwima St (M-CITY), 25 - 57 Legionów St (TONE), 26 - Academy of Fine Arts (no longer existing) (BEZT), 27 - 80 Wyszyńskiego St (INTI), 28 - 159 Wólczańska St (GREGOR), 29 - 'tódź Gallery' shopping mall (PROEMBRION), 30 - 52 Rzgowska St (3TTMAN)

Fig. 1. Location of murals in the Urban Forms Gallery in Łódź by tourism type (as at August 2014)

Source: own work based on www.urbanforms.org

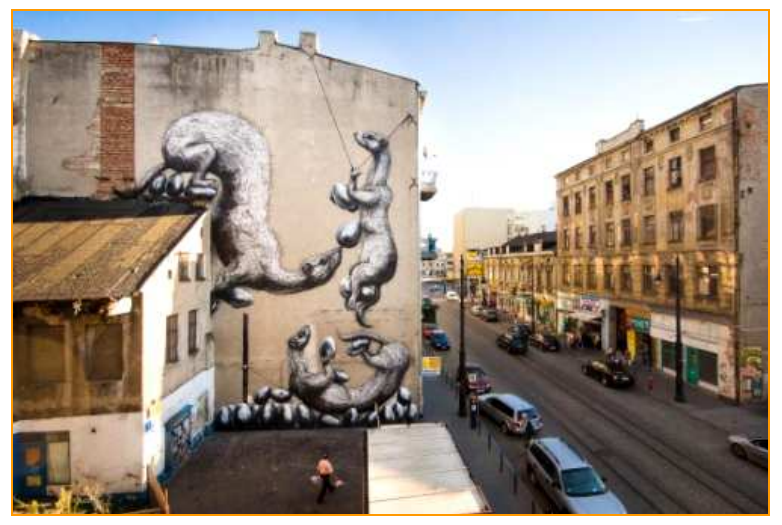

Photo 4. Mural at 5 Nowomiejska St, Łódź Source: www.urbanforms.org
- tourism space in the city centre,

- tourism space located away from the city centre, but important due to significant tourism assets,

- former non-tourism space situated in the city centre,

- former non-tourism space situated away from the city centre, close to industrial areas and on housing estates.

Murals located in the city centre tourism space in Łódź include 5 Nowomiejska St (Photo 4), 5 Roosevelta St (Photo 5), 9 \& 11 Próchnika St, 32 Kościuszki St, 109 \& 159 Wólczańska St. The murals are located close to Piotrkowska St (main tourism attraction in Łódź) and although they are not directly visible, they constitute a unique and easily accessible tourism offer or the addition to the basic. Moreover, the mural at 5 Roosevelta St also has additional artistic value near to the OFF Piotrkowska Centre (connected with alternative activities, 'off-culture' and modern art) ${ }^{7}$.

An interesting group of murals are those in the former non-tourism spaces in the city centre including such examples as 67 Pomorska St, 25 Pogonowskiego St (Photo 6) and 81 Nawrot St (Photo 7). Their appearance on the walls of downtown tenement houses has resulted in raising the quality and tourism attractive-ness of a previously neglected area.

Another group of murals is situated away from the city centre, but close to significant tourism assets (thus also in the tourism space of Łódź). An example is the mural in 82 Wojska Polskiego St (Photo 8), which is situated in a former Łódź Ghetto area, close to the Jewish Cemetery in Bracka St, Survivors Park and a museum exhibition about the 'gypsy camp' in the Łódź Ghetto. Therefore it can be stated that although the tenement house is located in a neglected part of the city, the appearance of the mural has raised its aesthetic value, rank and prestige and has thus enriched tourism space.

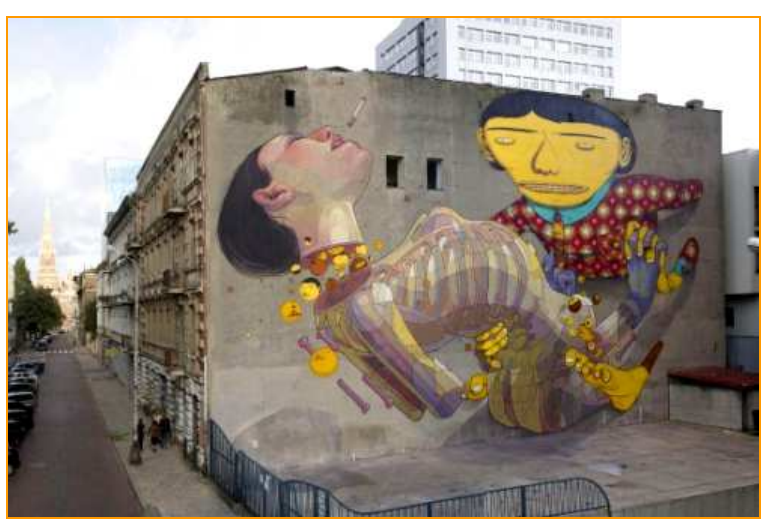

Photo 5. Mural at 5 Roosevelta St, Łódź Source: www.urbanforms.org 


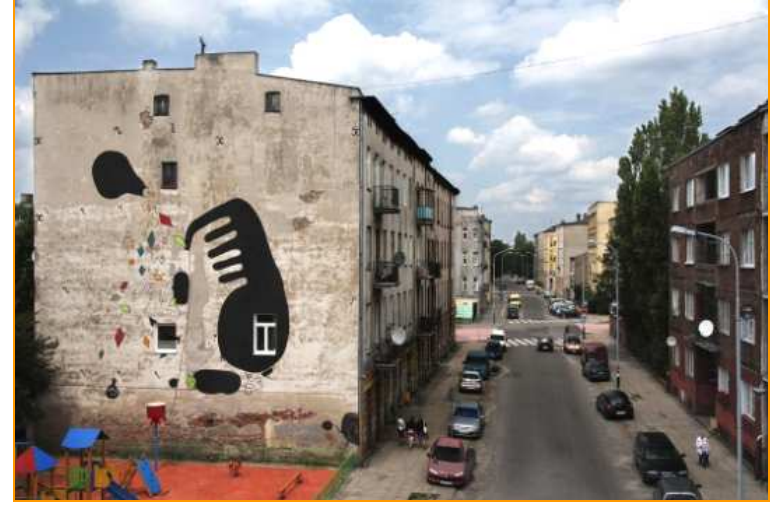

Photo 6. Mural at 25 Pogonowskiego St, Łódź Source: www.urbanforms.org

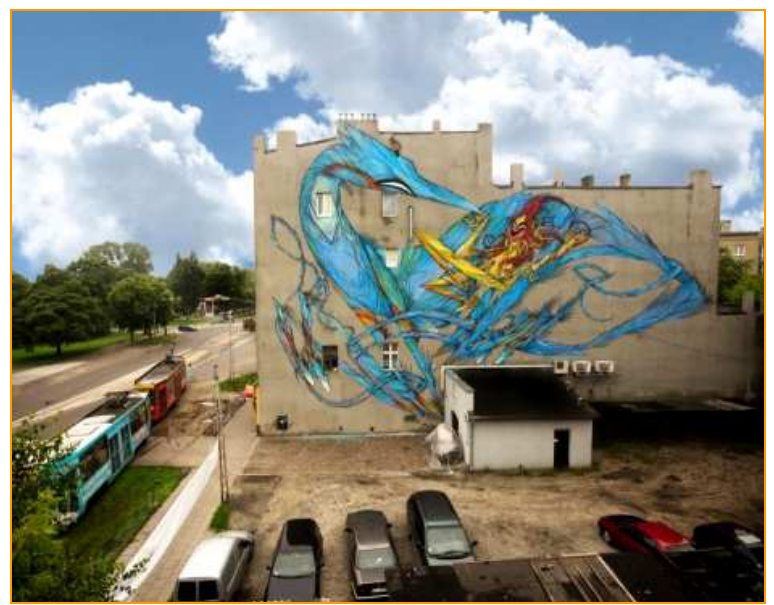

Photo 8. Mural at 82 Wojska Polskiego St, Łódź Source: www.urbanforms.org

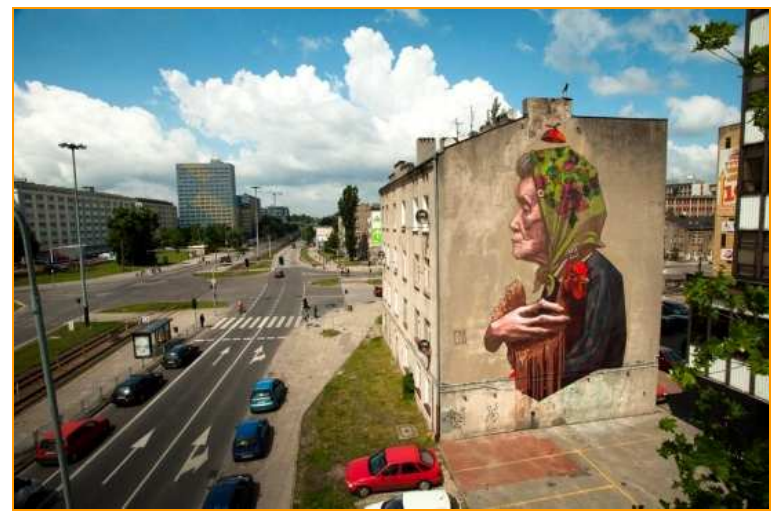

Photo 10. Mural at 16 Politechniki St, Łódź Source: www.urbanforms.org

An interesting example of the creation of a new, attractive place in Łódź by an accumulation of murals is 3 \& 12 Uniwersytecka St (Photo 9) and the mural in 59 Jaracza St situated close by. According to the opinion of local residents they are identified with each other and often mentioned together.

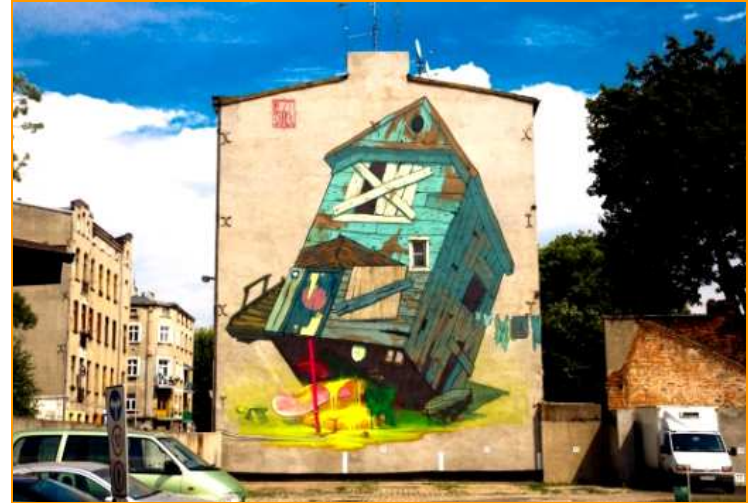

Photo 7. Mural at 81 Nawrot St, Łódź Source: www.urbanforms.org

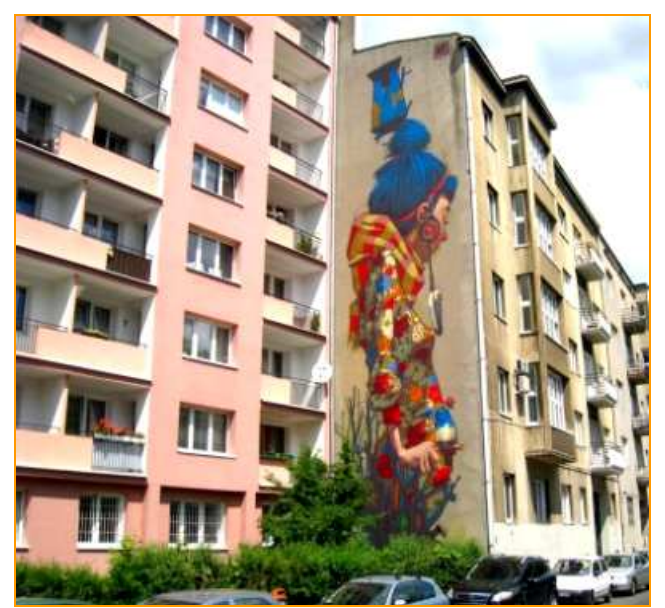

Photo 9. Mural at 12 Uniwersytecka St, Łódź Source: www.urbanforms.org

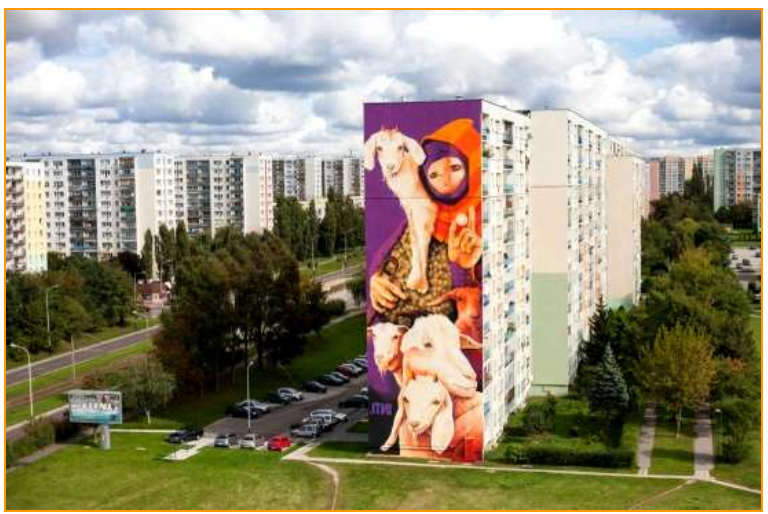

Photo 11. Mural at 80 Wyszyńskiego, Łódź Source: www.urbanforms.org

Another example of former non-tourism space (unknown, unwanted) is one located away from the city centre, close to industrial areas (mural at 16 Politechniki St, Photo 10) and on housing estates. The mural at 80 Wyszyńskiego St (wall of an apartment block) constitutes an excellent example of enlarging the 
tourism space of the city (Photo 11). Housing estates from the 1980s have not until now been a place of tourism interest.

All murals are an element of art-tourism space, a new one for Łódź, which can be extended by other assets and activities connected with street art. An example is 'art-in-the-meantime' - using the pavements in the front of six bus stops.

They were created by graduates of the Eódź Academy of Fine Arts and are an excellent example of activities that take place both in tourism space (e.g. Kilińskiego/Tuwima bus stop) as well as in nontourism space which, with tourists, is transformed into tourism space (e.g. Łódź Academy of Fine Arts/Palki bus stop).

\section{CHARACTERISTIC FEATURES OF ART - TOURISM SPACE IN ŁÓDŹ: URBAN FORMS GALLERY}

Five types of tourism space can be singled out: penetration, exploration, assimilation, colonization and urbanization (LISZEWSKI 1995, pp. 87-103). Three of them appear in art-tourism space:

- tourism exploration space which results from an individual discovering of the city. Tourists not satisfied with sites recommended in guidebooks, seek something interesting, original and unknown. This kind of tourism space is most remarkable for activities connected with modern art (also with street art), with individual tourism exploration and interpretation, as well as with the specific sensitivity of its audience;

- tourism penetration space, a part of cognitive tourism, usually by mass tourists. An important 'convenience' here is tourism infrastructure such as trails, museums and galleries (e.g. guided tours organized along the Trail of Murals in Łódź);

- tourism assimilation space which means mutual contacts between artists (organizers of the space) and tourists. It may refer to observations of artists at work, as well as to participation in street art activities (e.g. performances).

There are different types of comprehension level for art-tourism space and four can be singled out (WŁODARCZYK 2009, p. 80).

The first and the most important is 'real space', actually experienced, a sum of places connected with art and visited by tourists.

The second is perceptual space (also called mentalperceptual space), a kind of memorized space. It is usually incomplete and hierarchical in terms of mean- ing and value. In the case of modern art, especially large format artworks in an urban space, it is a set of ideas about them. Some experiences are rejected by tourists who over-simplify them and thus distort the art form.

The next is a virtual space, a kind of unreal space arising on the basis of secondary sources. It is not directly experienced, and sometimes faked or blurred. In the case of art-tourism it is well developed due mainly to colourful photos in guidebooks, brochures or on websites. Secondary sources present, however, a strongly idealised image - full of colours and strong visual stimuli.

The last kind is mental space, symbolic, resulting from consciousness, mind, thoughts and feelings and a derivative of the other three. It is also an expression of the tourist's system of values on the basis of strong associations, e.g. 'Eódź - city of murals', 'Eódź - city of contemporary art' etc.

\section{SUMMARY}

The development of new tourism spaces results in new motivations for tourists who, apart from 'traditional sightseeing', increasingly want to know areas 'off-the-beaten-track' and explore the urban fabric in a new way. Art-tourism space in Łódź is an expression of new activities connected with modern art including in particular the Urban Forms Foundation project of a 'live gallery' of murals. Their perfect background is the post-industrial landscape of the city and its traditions of the avant-garde, dating back to the interwar period. This space, singled out from general tourism space, colonises new areas, perceived previously as not attractive. Through the renovation of the neglected walls of tenement houses or through the appearance of murals on the elevations of apartment blocks on housing estates, tourism space expands.

Tourism space, as discussed in the paper, is not an easy space. Although murals are perceived mainly through their colour composition, interpretation requires mental effort, the engagement of the audience and a sharpening of the aesthetic senses.

\section{FOOTNOTES}

${ }^{1}$ A new sector of the economy based on innovative activities in the field of art, media and design. Among creative industries: film, video, architecture, music, performing arts, craft and design can be singled out (www.kreatywna.lodz.pl).

2 Independent, alternative culture.

3 Patterns are cut, then sprayed and placed on the walls of buildings. 
${ }^{4}$ Handmade stickers.

${ }^{5}$ Pieces of paper cut into appropriate shapes stuck on the walls.

${ }^{6}$ Large format artworks on the walls of buildings.

${ }^{7}$ www.offpiotrkowska.com.

\section{BIBLIOGRAPHY}

AFFELT W.J., 2009, Technoestetyka, czyli moc oddziatywania zabytku techniki.

Dialogi wokót murali. Raport z badań opinii przeprowadzonych w ulicznych punktach konsultacyjnych, 2014, Urban Forms, Łódź.

DOMAŃSKI B., 2010, Rewitalizacja miast polskich - wybrane zagadnienia, [in:] Rewitalizacja miast polskich jako sposób zachowania dziedzictwa materialnego $i$ duchowego oraz czynnik zrównoważonego rozwoju. Podsumowanie projektu, Instytut Rozwoju Miast, Kraków.

KACZMAREK S., 2001, Rewitalizacja terenów poprzemystowych. Nowy wymiar w rozwoju miast, Wyd. Uniwersytetu Łódzkiego, Łódź.

KRONENBERG M., 2012, Wptyw zasobów dziedzictwa przemystowego na atrakcyjność turystycznq miasta, Wyd. Uniwersytetu Łódzkiego, Łódź.

LISZEWSKI S., 1995, Przestrzeń turystyczna, „Turyzm”, 5, 2, pp. 87-103.

LISZEWSKI S., 1999, Przestrzeń turystyczna miasta (przykład Łodzi), „Turyzm", 9, 1, pp. 51-73.
LISZEWSKI S., 2005, Przestrzeń turystyczna w ujęciu podmiotowym. Przyczynek do dyskusji o przestrzeni w geografii, [in:] Geografia jako nauka o środowisku, przestrzeni i krajobrazie, t. 1: Podstawowe idee i koncepcje w geografii, ŁTN, Łódź.

LISZEWSKI S., 2008, Miasto jako przedmiot badań geografii turyzmu $w$ Polsce, "Turyzm", 18, 1, pp. 27-38.

NIŻYŃSKA A., 2011, Street art jako alternatywna forma debaty publicznej w przestrzeni miejskiej, Trio, Warszawa.

NOWACKI M., 2011, Autentyczność atrakcji a autentyczność doświadczeń turystycznych, „Folia Turistica”, 23.

STASIAK A., 2013, Nowe przestrzenie i formy turystyki w gospodarce doświadczeń, „Turyzm/Tourism”, 23, 2, pp. 65-74.

STĘPIEŃ B., 2010, Łódzkie murale. Niedoceniona grafika użytkowa PRL-u, Wyd. Księży Młyn, Łódź.

"Strategia zarządzania marką na lata 2010-2016", Urząd Miasta Łodzi, Łódź.

WŁODARCZYK B., 2009, Przestrzeń turystyczna. Istota, koncepcje, determinanty rozwoju, Wyd. Uniwersytetu Łódzkiego, Łódź.

WŁODARCZYK B., 2011, Procesy ksztattujące przestrzeń turystyczna, „Turyzm/Tourism”, 21, 1-2, pp. 59-66.

www.offpiotrkowska.com.

www.urbanforms.org.

www.monopolis.lodz.pl.

www.fashionweek.pl.

www.lodzdesign.com.

www.galeria-lodzka.pl.

www.murale.mnc.pl.

www.wi-ma.org.

www.lodzartcenter.com.

www.panoramio.com. 